\title{
The Formation of Key Competences in the Training Process of Preschool Education Specialists (Experience of the United Kingdom, Germany, Ukraine)
}

\author{
Larysa V. Zdanevych ${ }^{1}$, Kateryna L. Kruty ${ }^{2}$, Tetiana M. Tsehelnyk ${ }^{1}$, Leonida S. Pisotska ${ }^{1}$ \& Nataliia V. Kazakova ${ }^{3}$ \\ ${ }^{1}$ Department of Pre-School Pedagogy, Psychology and Professional Methods, Faculty of Pre-School Education and \\ Psychology, Khmelnytskyi Humanitarian-Pedagogical Academy, Khmelnytskyi, Ukraine \\ ${ }^{2}$ Department of Preschool and Primary Education, Faculty of Pre-School, Primary School and Arts Named after \\ Valentina Voloshina, Vinnytsia Mykhailo Kotsiubynskyi State Pedagogical University, Vinnytsia, Ukraine \\ ${ }^{3}$ Pedagogy Department, Faculty of Primary Education and Philology, Khmelnytskyi Humanitarian-Pedagogical \\ Academy, Khmelnytskyi, Ukraine
}

Correspondence: Larysa V. Zdanevych, Khmelnytskyi Humanitarian-Pedagogical Academy, 139 Proskurivskoho Pidpillia str., Khmelnytskyi, 29013, Ukraine.

Received: June 10, 2020

Accepted: August 3, 2020

Online Published: August 7, 2020

doi:10.5430/ijhe.v9n7p196

URL: https://doi.org/10.5430/ijhe.v9n7p196

\begin{abstract}
The article outlines the main prerequisites for the transformation of modern competences in the training process of preschool education specialists (experience of the United Kingdom, Germany, Ukraine). Differences in the training of future preschool education specialists are found in the structure and content of educational programs (curriculums), namely: the bachelor's training of preschool teachers is applied in Germany, as well as master's programs for training of preschool education specialists; the development of new forms and methods of teaching occupies an important place in advancing of professional teacher education in the UK; they make it possible to create the future teachers' ability for independent and critical thinking, the practical application of acquired knowledge and experience in educational research, role-based and simulation modeling, and creative search. In terms of professional competences, the most advanced training system of preschool teachers is revealed in the UK. However, in Germany, the process of training specialists in preschool education area was determined by institutional decisions, where preschool education was a form of childcare and part of social security. The United Kingdom is characterized by a longstanding tradition of a detailed, comprehensive framework of teacher's competences for training of preschool teachers. Therefore, one of the core competences is professionalism and standards in combination with such competences, as: values, knowledge and skills. As opposed to Germany and the United Kingdom, in Ukraine the formation of key competences in the process of training specialists in preschool education is primarily based on professional basic knowledge and skills, values and attitudes, motives of pedagogical activity.
\end{abstract}

Keywords: competences, preschool education, pedagogical competence, project competence, linguistic and communicative competence, methodological competence

\section{Introduction}

Currently, the importance of processes related to the social development of the child is increasing in the conditions of humanization of modern education. Accordingly, the role of preschool education as a factor in the successful development of the child is also growing. The tendency to consider preschool education is more clearly expressed not only as a stage of general education, approved at the legislative level, but also as an important phase in the education and upbringing of preschool children. This places a serious responsibility on preschool education, strict observance of educational standards requirements, as well as improving the quality of its content, accessibility and the possibility of choice by the child as a subject of the educational process. Modern researchers note (Zdanevich, 2019) that the new paradigm of pedagogy shifts the center of problems in the formation of knowledge, skills to the holistic development of a child's personality. European Parliament and Council of the European Union approved the Framework Program of updated core competences for lifelong learning on January 17, 2018. These competences 
include: literacy, language competence, mathematical competence, personal, social and educational competence, digital competence, civic competence, cultural awareness and expression competence, entrepreneurial competence.

Consequently, Sustainable Development Goal 4 "Provision a comprehensive and equitable quality education and promoting lifelong learning for all" determines indicators of its achievement under paragraph 4.2. to ensure for all girls and boys $100 \%$ access to quality systems for the development by 2030, as well as care and preschool education of young children, so that they are ready to receive primary education (global goals) and to ensure access to quality preschool development for all children (national goals), within paragraph 4.c "By 2030, substantially increase the supply of qualified teachers, including through international cooperation for teacher training in developing countries, especially least developed countries and small island developing States". Proportion of teachers who have received at least the minimum organized teacher training accounted for 80,57\% in 2015 in the lower-middle-income economies (to which Germany, the United Kingdom and Ukraine belong according to the World Bank's 2019-2020 classification).

An urgent need for society and the personality of the child is the training of a competent specialist who should be competitive in the market of educational services and meet the requirements of European and world level. In the European countries, the flexibility of the training programs, the passing of pedagogical practice in special educational centers, the scientific direction of vocational training, applying of active teaching methods, information and communication technologies, the increased attention to the quality control of training are common steps in training of future preschool teachers.

The pedagogical competences of a preschool educatation specialists are transformed in response to a number of trends, implemented in modern society. The basic determinative trends are as follows: a clear specification of competences in developed countries; development of the legal framework that determines the specification of competences; introduction of lifelong learning and professional development of preschool educatation specialists throughout life. The specified trends determine the relevance and objectives of the study.

The purpose of the study is to analyze the experience of forming the competences of preschool education specialists on the example of Ukraine, the United Kingdom and Germany.

The basic objectives of the academic paper are:

- analysis of historical experience concerning the development of competencis of preschool education specialists on the example of Ukraine, the United Kingdom and Germany;

- analysis of the legal framework of regulation in the sphere of formation of competences of preschool education specialists on the example of Ukraine, the United Kingdom and Germany;

- formation of a list of competences of preschool education specialists in order to provide recommendations for Ukraine.

\section{Literature Review}

In 2006 European Council and European Parliament implemented a Recommendation on Key Competences for Lifelong Learning; in particular, the main competence of learning to learn (due to change, selecting and managing from information flows) stands out among main eight competences (civic competences, digital, learning to learn) (European Commission, 2013).

The document, supporting the Teaching Professions for better learning outcomes (European Commission, 2013) has noted that teaching staff "will increasingly need the competences to find, evaluate and deploy learning materials from a wider range of sources', as well as 'critical, evidence based attitudes, enabling them to respond to students' outcomes, new evidence from inside and outside the classroom, and professional dialogue, in order to adapt their own practices'. There is an agreement that, for teachers, the development and acquisition of competences needs to be viewed as a career-long endeavour.

In the UK structured frameworks were developed - detailed lists of competences (as lists of knowledge, skills, values or attitudes; providing can-do statements or indicators; distinguished by subject area or/and school level), often linked to career advancement and professional standards. These frameworks describe different levels of expertise in general - such as the "beginner" or the "advanced teacher". A main focus on teacher competence in Germany is linked to reforms. In Germany, the Standing Conference of Ministers of Education and Culture (Kultusminister Konferenz, 2004) has agreed detailed standards in subject and specific matters, as well as Bildungswissenschaften (including psychology, pedagogy, and sociology) (Rauschenbach \& Riedel, 2016); these are recommendations in ministries of the different Länder for policy makers. These standards, broken down into specific and detailed lists of 
competences, are the bases for recognition and implementation of final examinations across the Länder. The specific competences are developed as guidelines for programs for initial teacher education at Universities; they are in line with the competences to be developed in the Second Phase of teacher education and in CPD, especially in the Länder with a high awareness of the continuum of teacher education based on an integrated approach. In 2009 the KMK published a concept note for the use of these 'Bildungsstandards' for classroom development and management.

In the context of our study, we focus on pedagogical competence - this is primarily an integral professional and personal characteristic of a teacher, which allows him to be ready and able to perform pedagogical functions in accordance with the norms, state standards, and requirements of recent time (Kravets, 2018). A number of competences of preschool teachers are determined in the scientific literature, namely: "project competence" (Koshil, 2018), "linguistic and communicative competence" (Dzhendzhero \& Diatlova, 2018), intellectual competence, information competence, lifelong learning, communicative competence, moral and cultural competence, creative competence, organizational and managerial competence, psychological competence, mathematical competence, professional and methodological competence, social competence, preservation of health competence (Kravets, 2018). Methodical competence is one of the important components of a teacher's professional competence. The person-centered component of methodological competence is in correlation with skills, related to the psychological component of the teacher's personality. The activity-related component includes the accumulated professional knowledge and skills, the ability to update them at the right time and to use them in the process of implementing their professional functions. The cognitive component is based on the skills that make up the theoretical training, namely: analytical and synthetic (the skill to analyze programmatic and methodological documents, the skill to classify and organize methodological knowledge); prognostic (the skill to predict the effectiveness of selected tools, forms, methods and techniques, the skill to apply methodological knowledge); construction and design (the skill to generalize the learning process, the skill to plan methodical activities) (Naboka \& Demchenko, 2017).

Kalichak (2018) in his study has highlighted the components of professional competence, namely: key, basic and special ones. Key competences are understood as the ability to solve professional tasks based on the use of information, communication, social and legal foundations of personality behavior in civil society. Basic competences are a combination of universal and subject-specific competences, reflecting the specifics of certain professional pedagogical activity. Special competences are the result of the integration of key and basic skills, necessary for the implementation of professional activities in a specific field.

In the study of Nessipbayeva (2012), the following modern competencies of the teacher have been identified, namely: cultural competence, talent, innovation, creativity, critical thinking, problem solving.

Manning, Garvis, Fleming and Wong (2017) in their study have assessed the correlation between teacher qualifications and quality indicators of educational space in preschool institutions (according to the ECERS, ECERS-R scales). A sample of 82 independent studies was used for the meta-analysis: an assessment of the quality of the educational environment in the institution of preschool education as a whole was made in 58 of them, an assessment was made using scales for assessing educational space with subscales in 24 of them. The interrelation between teacher qualifications and the quality of the educational environment in preschool education gives a statistically significant positive correlation (average correlation with significance level $\rho=0.80 ; \mathrm{r}=0.198$ ). The results of the study also reveal a positive, statistically insignificant correlation between the teachers' qualifications and the organization of training; positive, statistically insignificant correlation between the qualifications of teachers and the quality of communication and language use.

The conceptual basis of the study envisages the assumption that knowledge and competences in the training process of preschool teachers, a set of professional competences, skills and abilities provide high-quality preschool education and positive results of child's development (Bowman, Donovan, \& Burns, 2001; Vartuli, 1999). Berk (1985) has established that teachers with the 3rd education level (secondary vocational / higher) (for example, Associate degree (AA) or Bachelor's degree (BA)), regardless of the specifics of the subject, were more sensitive, possessing a high level of skills in providing support, effective communication with preschool children. On the other hand, scientist found that existence of higher level of knowledge in education is important for developing higher-level pedagogical skills (Grotewell \& Burton, 2008). This concept finds scientific endorsement, proving that the views and principles of the teacher, knowledge and implementation of relevant age programs are directly related to the quality of preschool education (McMullen, 1998; Vartuli, 1999). Students who receive training under programs related to child's development, are also more and more likely to prefer classes according to the age of children than students enrolled in other programs. Teachers with Bachelor's degree or those who have graduated from a two-year college in a specialty, related to preschool education and child's development, often find more sensitive attitude and less 
detached behavior (Howes, Whitebook \& Phillips, 1992). Moreover, it has been argued in the scientific literature that existence of high level of knowledge in the field of preschool education provides for the introduction of appropriate child's development by teachers (Vartuli, 1999); they are more likely to promote support and attentive engagement, which is significant for achieving high quality preschool education.

\section{Data and Methods}

General theoretical and special methods of research are used in the study, in particular, the dialectical method of scientific cognition has made it possible to trace the modern tendencies in the development of approaches to formation of competences of preschool teachers. The gnosiological method is the basis for the formulation of key terms and characteristics related to the subject of the study. The comparative method allowed carrying out a comparative analysis of teachers' competences in different countries. The analytical method has been used to formulate generalized and detailed conclusions based on the results of the study.

The study is based on the analysis of historical experience concerning the development of competences in the UK, Germany and Ukraine. At the first stage of the research a bibliometric analysis of scientific publications for the period 1985-2018 was conducted on the basis of the principle of historicism. Wiley Online Library, Taylor and Fransis Group, Google Scoolar databases have been used to search for publications according to the following basic criteria: country (Ukraine, Germany, the United Kingdom), period (1985 - 2018) in order to monitor the transformation of the process of training preschool education specialists; empirical results that showed the effectiveness and role of certain competences in the process of training. Empirical results were one of the search criteria that would make it possible to identify the effectiveness of key competences. The basic key words of the search were as follows: specialists in preschool education, the competences of teachers in the process of training, the effectiveness of teachers' competences.

The analysis was carried out with the aim of studying the transformation of countries' experience in developing competences in accordance with the needs of society. The result of the first stage of the study is displayed in a list of key competences of preschool education specialists during 1990-2018.

At the second stage of the research, a statistical analysis of the indicators of preschool education was carried out according to data of the UNESCO Institute for Statistics (Sustainable development goal (SDG) 4, 2020a, 2020b, 2020c) for the period 1999-2018; these data determine the features of the formation of key competences in the training of preschool education specialists. The following indicators of UNESCO Institute for Statistics and World Bank have been selected to conduct an analysis, namely:

1. Preprimary education, duration (years) in the United Kingdom, Germany, Ukraine 1999-2018, pupils.

2. Preprimary education in the United Kingdom, Germany, Ukraine, pupils.

At the third stage, the standards' analysis of Germany and the United Kingdom, defining the key competences for training preschool education professionals, has been conducted:

1. The UK teachers' standards.

2. Germany teachers' standards Bildungswissenschaften.

As a result, differences in the state of preschool education between countries have been revealed. At the third stage of the research, an analysis of the legal framework for regulating the competences and features of the educational process in the training of preschool education specialists was conducted. The comparison of the basic competences of specialists between countries was carried out as the result of this stage.

\section{Results and Disscusion}

Training of pedagogical personnel is carried out at universities, institutes of higher education, institutes of pedagogy of the universities, pedagogical colleges. Differences in training of future preschool teachers are reflected in the structure and content of curriculum, namely: the bachelor's training of preschool teachers is applied in Germany, as well as master's programs for training of preschool education specialists; in the UK the development of new forms and methods of teaching occupies an important place in advancing of professional teacher education; they make it possible to create the future teachers' ability for independent and critical thinking, the practical application of acquired knowledge and experience in educational research, role-based and simulation modeling, and creative search (Table 1). A new approach to learning is connected with this direction as the organization of educational, searching and research activities; educational play-based modeling activities; active exchange of views, creative discussion. Studying of current realities of British professional pedagogical education suggests that the guiding line in the 
training of the future teacher is the formation of an intellectual, moral, creative specialist who is able to creatively program instruction and behavior in the educational process organized by him (Kozak, 2017).

Table 1. UNESCO MIL Curriculum Goals and Teacher Skills

\begin{tabular}{|c|c|c|}
\hline Curriculum Area & Curriculum Goals & Teacher Skills \\
\hline Vision and policy & $\begin{array}{l}\text { To sensitize to the vision } \\
\text { and policies needed for } \\
\text { MIL }\end{array}$ & $\begin{array}{l}\text { Teachers should know and understand policies that necessary } \\
\text { to promote MIL; how these can be realized in education and } \\
\text { society). Teachers should understand how MIL impact to } \\
\text { broader development and life skills within the context of } \\
\text { education }\end{array}$ \\
\hline
\end{tabular}

Assessment curriculum

Information literacy and media

Administration and organization

Pedagogy

Teacher develop professionalism
To enhance knowledge of the range of information providers and media such as the Internet libraries and archives

To enhance capacity of teachers' to organize the classroom space for participation in all teaching, and for information resources and media to be an integral part of achieving

To impact change in teachers' practices that necessary to teach about information literacy and media

Teachers understand how media information and literacy might be utilized in the school curriculum. Teachers should be able to assess critically information sources and media texts to information providers in the light of the functions attributed. In addition, for that goal to select a range of material from information resources and media. Teachers must have skills to assess understanding of MIL of students

Teachers should understand and know how media and information providers have evolved into modern forms. Teachers should improve and develop skills in using technologies to reach audiences, from print-based media to new media. They should be able to use different information resources and media to develop skills and extend these to their and critical thinking.

Information-literate and media teachers must understand classroom organization proccesses; teachers are able to create conditions in teaching that maximize the use of information providers for education and lifelong learning, including skills in organizing learning in such ways that make the classroom a space which respects perspectives irrespective and different views of gender and background.

Information-literate and media teachers must acquire the pedagogical skills in order to teach information literacy and media to students. They must have the ability to teach and learn MIL from the perspective of intercultural dialogue, good governance, and development. They must acquire knowledge about interactions of student with, and response to, media as an initial step in supporting information-literacy and medialearning.

Teacher should have the range of skills in order to use technology and media to acquire subject matter and access information and pedagogical knowledge in order to support of own professional development.

information resources and media for professional development and life-long learning

Source: UNESCO (2011)

Scotland's Curriculum for Excellence, which is still being implemented and was launched in SY 2010-11, embraces a lot of competence education concepts. Curriculum guidelines embrace national standards and it very specific about learning outcomes; permit education authorities on local level and schools autonomy in creating the curriculum that delivered to students. As in British Columbia, the curriculum is less granular than its predecessor, anticipating that 
teachers will work together to share their understanding of expectations and standards of performance through moderation activities and professional discussion. The new curriculum focuses on relentless formative assessment in the classroom, a "show what you know" pedagogical strategy, learning goals that are articulated by students, and the needs of the holistic well-being of the students. As outlined in professional development document, students are expected to clearly articulate and understand their learning goals (Bristow \& Patrick, 2014).

The formation of key competences in the process of training preschool education specialists in the countries depends on such prerequisites: number of children and teachers, features of preschool education, forms and methods of education, labor market, availability of standards and requirements for teaching staff, etc.

Over the period 2013-2018 there was an increase in the length of stay in preschool institutions in the UK, Germany and Ukraine: from 3 years to 6 years in Germany, from 2 years to 4 years in the UK, from 3 years to 5 years in Ukraine. In 2013, School enrollment, preprimary (\% gross) in Germany was - 107.52\%, in the United Kingdom $79.30 \%$, in Ukraine - 83.87\% (Figure 1). This points to significant differences between the preschool education system in Germany, the UK and Ukraine. In Germany, a high ratio may point at substantial number of overage children enrolled in each grade because of repetition or late entry rather than a successful education system. Herewith, in 2017, the indicator for Germany was $109.12 \%$, for the UK $-106.38 \%$.

There are differences in the number of children in preschool education institutions in the United Kingdom, Germany and Ukraine (Figure 2): in Ukraine and in the UK the number of children is decreasing, in Germany it remains constant. At the same time, the number of children in preschool institutions is also different: for example, in Germany 2954775 children are enrolled in preschool education in 2018, in the UK - 4820283 children, in Ukraine 1676550 children. While in the UK and Germany the number of children is significantly higher than in Ukraine, the pupil-teacher ratio in Ukraine and Germany is at the same level (8 preschool children per teacher in Germany in 2017 and 9 in Ukraine in 2012), whereas in Great Britain - 62 children per specialist in preschool education (UNESCO Institute for Statistics, 2020b).

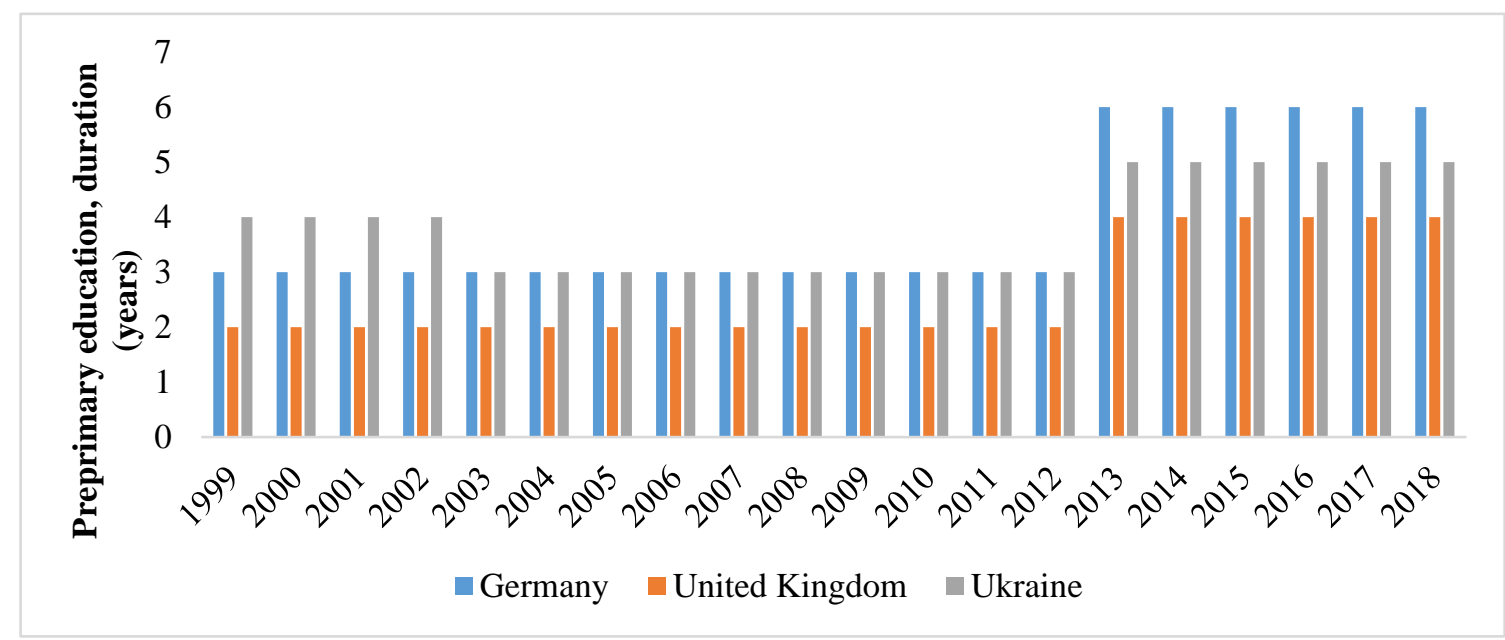

Figure 1. Preprimary education, duration (years) in the United Kingdom, Germany, Ukraine 1999-2018, pupils Source: Sustainable development goal (SDG) 4 (2020a, 2020b, 2020c), UNESCO Institute for Statistics (2020a) 


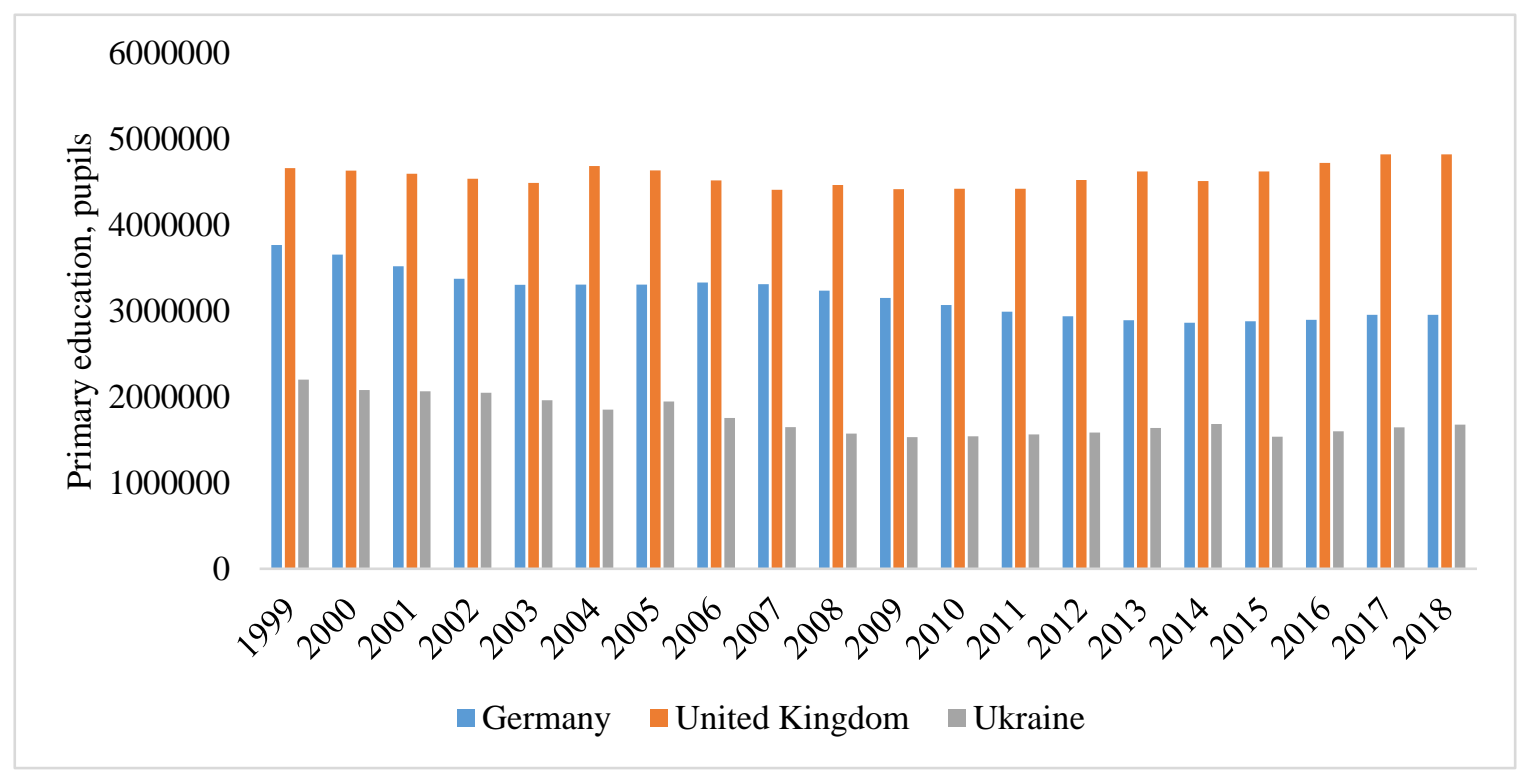

Figure 2. Preprimary education in the United Kingdom, Germany, Ukraine, pupils

Source: Sustainable development goal (SDG) 4 (2020a, 2020b, 2020c), UNESCO Institute for Statistics (2020b)

Herewith, in Germany there is a tendency to decrease the indicator for reducing the number of children in preschool education. Such tendencies cause differences in the training of preschool education specialists. While the indicator is growing in Ukraine and the UK, the participation rate in organized learning (one year before the official primary entry age) in Germany was $98,75 \%$ in 2017 , in the UK $-99,93 \%$.

The guidelines about the competences required to be used for training in Germany (for instance, reflective or methodological competences) are usually embedded in national curricula, as references for initial teachers' education or continuous professional development. Autonomy is left to college or university providers in order to develop and apply competence requirements in teachers' curricula. Alon with this, structured frameworks are applied in the UK, that is, detailed lists of specific competences (as lists of knowledge, skills, values or attitudes). They provide can-do statements or indicators. They are also distinguished by school level and/or subject area), and often linked to career advancement and professional standards (European Commission, 2013).

Compared to other European countries, the process of training specialists for preschool education in Germany was determined by institutional decisions, where preschool education was a form of childcare and part of social security (Krutiy, 2020). A privileged position in preschool education was held by voluntary associations and churches. The system of preschool education was decentralized, which determined the features of competencies in the training of preschool teachers. This led to significant differences between the education of preschool children in Germany and the UK. Only over the last ten years, certain changes have occurred in Germany: there has been a change in approaches to the definition of professional competences and a change in the traditional concepts of the profession (Rauschenbach \& Riedel, 2016).

Peculiar features of preschool education in Germany center around various types of preschool institutions aimed at different categories of children, using different teaching and upbringing methods. However, the Frobel method is the basis of every German kindergarten's curriculum. The development of the child's personal abilities taking into account interests and preferences is a prime objective in learning. The general system of educational institutions in Germany does not include nurseries and kindergartens, which has led to the development of private preschool education. Preschool education in Germany is optional, it is not controlled at the state level. This determines the competencies of the teachers and the process of their training. Institutions differ in teaching methods: Montessori system, Waldorf education, Frene pedagogy. International kindergartens have become widespread. This has determined the need to acquire the competence of bilingualism and multilingualism. The main skills that preschooler should acquire in Germany include: sociability, curiosity, patient attitude to others, empathy, respect for norms and rules, as well as the ability to express their opinion. Official entrance age (years) of preschool education is 3 years (UNESCO Institute for Statistics, 2020c, 2020d). Government expenditure on education as \% of GDP is 4, 8\% and $10,9 \%$ of total government expenditure in 2016. In the UK, these indicators are 5, 5\% and 13, 8\%, respectively, in Ukraine $-5,4 \%$ and $13,1 \%$, respectively. 
The United Kingdom is characterized by a longstanding tradition of a detailed, comprehensive framework of teacher's competences for training of preschool teachers (Cassidy, Buell, Pugh-Hoese \& Russell, 1995; Pound \& Buckingham, 1992). That is why, professionalism is one of the basic competences.

Until 2000, the preschool system for children aged 3-5 in the UK was focused on upbringing and education in the context of training to school at the age of 5 years old, rather than a stage of early childhood experience with a focus on game activities (Macleo \& Jones, 2000).

UK teacher standards were introduced in 2000 in government guidelines concerning primary education. The instructions are common for teachers of all levels and subjects; they determine the features of the various stages of a career and professional profile. A detailed, analytical structure has been created in the UK based on the interaction and dependence of such qualities, as: values, knowledge and skills. These competences are divided into specific lists of requirements and indicators (Table 2).

Table 2. Teachers' competences in the UK and Germany according to the governments' srandards

\begin{tabular}{l} 
Country \\
\hline The UK \\
Inspire, motivate and challenge pupils \\
Promote progress and outcomes achieved by pupils \\
Subject and curriculum knowledge \\
Plan and teach well structured lessons \\
Adapt teaching to respond to the strengths and needs of all pupils \\
Make accurate and productive use of assessment \\
Manage behaviour effectively to ensure a good and safe learning environment \\
Fulfil wider professional responsibilities \\
Germany $\quad$ Competence to cooperate with other people, as well as with other professional establishments and \\
institutions \\
Ability to work in conflict situations and resolve them \\
Motivation of students \\
Skills of differentiation, integration and promotion \\
Skills to assess the productivity of the educational process \\
Communication skills \\
Digital skills
\end{tabular}

Source: Department for Education of UK (2011); Kultusminister Konferenz (2004)

In Germany, the Standing Conference of Ministers of Education and Culture (KMK) approved detailed standards for the study of specific subjects by preschool teachers in Bildungswissenschaften (including pedagogy, psychology and sociology). Bildungswissenschaften is a set of recommendations for the development of competences in the procces of training of preschool teachers. These standards contain a detailed list of teacher competences (Chernobrovkin, 2018). Competences are understood as the guidelines for teachers at universities concverning curriculums for primary education specialists. In 2009, KMK published a concept for using these "Bildungsstandards" for audience management and development.

Strohmer and Mischo (2016) have determined in their study the development of preschool teachers' potential competences in the process of training of preschool teachers. The authors have conducted the assessment of preschool teachers' beliefs regarding the relevance of competences, their self-competence related to competence, and objective measures to obtain knowledge on the development of language skills. Based on a sample of 1120 future preschool teachers of various educational directions in Germany (vocational schools and universities), assessment of competences was conducted. The differences in subjective and objective competences between beginners and graduates, as well as between students of various curriculums were determined.

In Ukraine, the structure of professional competence of preschool education institutions' teachers is determined not only by professional basic knowledge and skills, but also by value-based orientations in the profession, characterizing the motives and preferences of the teacher, the ability to value knowledge, experience, relationships 
with people in the profession (Mashkina, 2019). Motives and privileges that stimulate pedagogical activity determine the effectiveness and performance of this activity. In the structure of the teacher's professional competence one should also highlight the personal qualities important for this professional profile, namely: intellectual culture, performance level of creative innovative methods and technologies, creative self-realization and development of cultural practices of other teachers (Bielienka, 2017). The development of teachers' professional competence of preschool educational institutions through a system of methodological measures is based on a differentiated approach based on a system analysis.

\section{Conclusion}

The conducted study makes it possible to formulate the following conclusions. Compared to other European countries, the training process of preschool teachers in Germany was determined by institutional decisions, where preschool education was a form of childcare and part of social security. This led to significant differences between the education of preschool children in Germany and the UK. The peculiarities of preschool education in Germany center around various types of preschool institutions aimed at different categories of children, using different teaching and upbringing methods.

The United Kingdom is characterized by a longstanding tradition of a detailed, comprehensive framework of teacher's competences in training process of preschool teachers. That is why, professionalism is one of the basic competences. Until 2000, the preschool system for children aged 3-5 in the UK was focused on upbringing and education in the context of training to school at the age of 5 years old, rather than a stage of early childhood experience with a focus on game activities. UK teacher standards were introduced in 2000 in government guidelines concerning primary education. The instructions are common for teachers of all levels and subjects; they determine the features of the various stages of a career and professional profile. A detailed, analytical structure has been created in the UK based on the interaction and dependence of such qualities, as: values, knowledge and skills.

In contrast to Germany and the United Kingdom, the formation of key competences in the process of preschool teachers in Ukraine is primarily based on professional basic knowledge and skills, values and attitudes, motives of pedagogical activity.

\section{References}

Berk, S. F. (1985). The gender factory. The apportionment of work in American households. New York, NY: Plenum Press. https://doi.org/10.1007/978-1-4613-2393-8

Bielienka, H. V. (2017). Professional training of preschool teachers: strategy of changes. Young Scientist, 3.2(43.2), 145-152.

Bowman, B., Donovan, M., \& Burns, M. (2001). Eager to learn: Educating our preschoolers. Washington, DC: National Academy Press.

Bristow, S. F., \& Patrick, S. (2014). An international study in competency education: Postcards from abroad. Retrieved

from https://aurora-institute.org/wp-content/uploads/CW-An-International-Study-in-Competency-Education-Postcard s-from-Abroad-October-2014.pdf

Cassidy, D. I., Buell, M. I., Pugh-Hoese, S., \& Russell, S. (1995). The effect of education on child care teachers' beliefs and classroom quality: Year one evaluation of the TEACH early childhood associate degree scholarship program. Early Childhood Research Quarterly, 10(2), 171-183. https://doi.org/10.1016/0885-2006(95)90002-0

Chernobrovkin, V. A. (2018). Professional preparation of a teacher of preschool education in modern conditions of development of the university: international experience of cooperation, basic directions and prospects of development. Modern high technology, 2, 164-168.

Department for Education of UK. (2011). Teachers' standards guidance for school leaders, school staff and governing bodies. Retrieved from https://assets.publishing.service.gov.uk/government/uploads/system/uploads/attachment_data/file/665520/Teach ers_Standards.pdf

Dzhendzhero, O. L., \& Diatlova, I. S. (2018). Individual linguistic-communicative competence as important structural component of the professional competence of future specialists in preschool education. Young Scientist, 2.1(54.1), 32-35.

European Commission. (2013). Supporting teacher competence development for better learning outcomes. Retrieved 
from https://ec.europa.eu/assets/eac/education/experts-groups/2011-2013/teacher/teachercomp_en.pdf

Grotewell, P. G., \& Burton, Y. R. (2008). Early childhood education: Issues and developments. New York, NY: Nova Science Publisher.

Howes, C., Phillips, D. A., \& Whitebook, M. (1992). Thresholds of quality: Implications for the social development of children in center-based child care. Child Development, 63(2), 449-460. https://doi.org/10.2307/1131491

Kalichak, Y. (2018). The formation of educator of institutions of preschool education in the process of professional training. Youth and the market, 6 (161), 66-69.

Koshil, O. (2018). Features of formation of project competence in future educators of preschool education institutions. Educational discourse, 1-2(20-21), 303-311. https://doi.org/10.28925/2312-5829.2018.1-2.9146

Kozak, L. (2017). Preparing forward specialists for preschool education: European experience. Continuing Professional Education: Ttheory and Practice (Series: Pedagogical Sciences), 3-4(52-53), 136-142. https://doi.org/10.28925/1609-8595.2017(3-4)136142

Kravets, L. M. (2018). Competence approach to preparation of preschool education professionals. Innovation in education, 1(7), 157.

Krutiy, K. (2020). Working remotely: Why do kids hunt bears in the Netherlands? Retrieved from http://ukrdeti.com/category/doshkillya-za-kordonom/

Kultusminister Konferenz. (2004). Standards for teacher education: educational sciences. Retrieved from https://www.kmk.org/fileadmin/veroeffentlichungen_beschluesse/2004/2004_12_16-Standards-Lehrerbildung-B ildungswissenschaften.pdf

Macleo, F., J. \& Jones, D. (2000). Early childhood education in England and Wales: Challenges and practices in the New Millennium. Early Child Development and Care, 164(1), 1-12. https://doi.org/10.1080/0300443001640101

Manning, M., Garvis, S., Fleming, C., \& Wong, G. T. W. (2017). The relationship between teacher qualification and the quality of the early childhood education and care environment. Retrieved from https://files.eric.ed.gov/fulltext/ED573516.pdf https://doi.org/10.4073/csr.2017.1

Mashkina, L. (2019). Formation of professional competence of future educators of preschool children in the educational process of higher education institutions. Youth and the market, 1(168), 81-84.

McMullen, M. B. (1998). The beliefs and practices of early childhood educators: Does specialized preparation make a difference in the adoption of best practices? International Journal of Early Childhood Education, 3, 5-30.

Naboka, O. G., \& Demchenko, M. A. (2017). Methodical competence of preschool educational institutions: Theoretical aspect. Young Scientist, 10.1 (50.1), 44-47.

Nessipbayeva, O. (2012). The competencies of the modern teacher. Retrieved from https://files.eric.ed.gov/fulltext/ED567059.pdf

Pound, L., \& Buckingham, M. (1992). Early childhood teacher education in the United Kingdom. Early Child Development and Care, 78(1), 25-42. https://doi.org/10.1080/0300443920780103

Rauschenbach, T., \& Riedel, B. (2016). Germany's ECEC workforce: A difficult path to professionalisation. Early Child Development and Care, 186(1), 61-77. https://doi.org/10.1080/03004430.2015.1014811

Strohmer, J., \& Mischo, C. (2016). Does early childhood teacher education foster professional competencies? Professional competencies of beginners and graduates in different education tracks in Germany. Early Child Development and Care, 186(1), 42-60. https://doi.org/10.1080/03004430.2014.985217

Sustainable development goal (SDG) 4. (2020a). Country profile. Germany. Retrieved from http://uis.unesco.org/sites/default/files/documents/countryprofiles/DE.pdf

Sustainable development goal (SDG) 4. (2020b). Country profile. Ukraine. Retrieved from http://uis.unesco.org/sites/default/files/documents/countryprofiles/UA.pdf

Sustainable development goal (SDG) 4. (2020c). Country profile. United Kingdom. Retrieved from http://uis.unesco.org/sites/default/files/documents/countryprofiles/GB.pdf

UNESCO Institute for Statistics. (2020a). Preprimary education, duration (years). Retrieved from https://data.worldbank.org/indicator/SE.PRE.DURS

UNESCO Institute for Statistics. (2020b). Primary education, pupils. Retrieved from 
https://data.worldbank.org/indicator/SE.PRM.ENRL

UNESCO Institute for Statistics. (2020c). Pupil-teacher ratio, preprimary. Retrieved from https://data.worldbank.org/indicator/SE.PRE.ENRL.TC.ZS

UNESCO Institute for Statistics. (2020d). School enrollment, preprimary (\% gross). Retrieved from https://data.worldbank.org/indicator/SE.PRE.ENRR

UNESCO. (2011). Media and information literacy curriculum for teachers. Retrieved from https://unesdoc.unesco.org/ark:/48223/pf0000192971

Vartuli, S. (1999). How early childhood teacher beliefs vary across grade level. Early Childhood Research Quarterly, 14(4), 489-514. https://doi.org/10.1016/S0885-2006(99)00026-5

Zdanevich, L. V. (2019). Specificity and regional peculiarities of preparation of future tutors in institutions of higher education of the countries of Western Europe and Asia pacific for professional activity. In H. Tsvetkova (Ed.), Professional development of the teacher in the light of European integration processes: collective monograph, 279-309. Hameln, Germany: InterGING. 